\title{
Experimental Study on Peripheral Tissue Response to Functioning Endosseous Dental Implant
}

(Changes in tissues peripheral to the endosseous implant which has been functioning in the mandible of Macacus Irus)

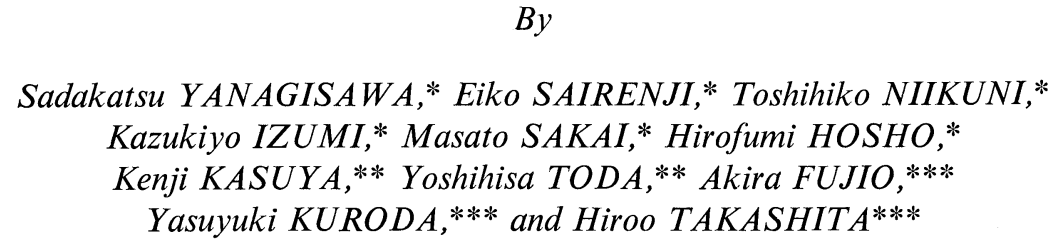

\section{Foreward}

Recently, dental implant modality has been applied clinically as one of the treatments for dental cripples.

There are various shapes of clinically used implants being devised and presented for different intended purposes. NIIKUNI et al.[1] have attempted to classify them in terms of insertion sites and shapes as follows:

1. Subperiosteal Implants

a) Full mandibular and maxillary S.I.

b) Pterygoid Extention I.

c) Universal S.I.

2. Endosseous Implants

a) Blade I.

b) Screw I.

c) Spiral-Post I.

d) Bi-Tripod I.

e) Cylindrical (Vitreous Carbon) I.

f) T-Type (Alumina Oxide) I.

g) Irregular form (bone, cartilage, proplast) I.

3. Endodontic-Endosseous Implants

a) Smooth pin I.

b) Threaded pin I.

4. Submucous Implant

5. Miscellaneous Implants

a) Rami-Endosseous Frame I.

b) Transosseous I.

\footnotetext{
* 節沢定勝, 西連寺永康, 新国俊彦, 泉 和清, 酒井正人, 宝渚博文, Radioisotope Research Laboratory

** 粕谷健次, 戸田善久, Department of Anatomy

*** 藤尾 昭, 黒田康久, 高下弘夫, Department of Physiology

(A part of this study was supported by the Grant-in-Aid for Scientific Research from the Ministry of Education, Science and Culture of Japan, Contract No. 248347)
} 
c) Arthroplastic I.

d) Maxillo-Facial I. (Proplast. silicone)

e) Endosseous-Subperiosteal I.

The materials used for these implants are metals (Ti, Ta, $\mathrm{Zr}, \mathrm{Co}-\mathrm{Cr}-\mathrm{Mn}$ ), inorganic materials (vitreous carbon, ITI, $\mathrm{Al}_{2} \mathrm{O}_{3}$, hydroxy-apatite), organic materials (silicone and teflon), and bio-materials (bone, cartilage, tooth).

While these various types and shapes of implants are being presented, a titanium blade implant is thought to be clinically one of the most superior implant, because it has wider adaptability, stronger stability and tissue tolerance which comes from inertness, lightness in weight, unbreakability of material, designability and geometry[2, 3, 4, 5 II.].

Previously we have reported the clinical and basic studies on endosseous blade implant $[6,7,8,9]$. Paralleling these studies, simulating animal model experiment has also been carried out for the purpose of observing the response and remodeling process of peripheral tissue to the functioning implant for an extended time span.

A few of histo-pathological studies on peripheral tissue around the implant have been reported. In these studies, experimental animals such as canine, swine, and rabbit had been widely used in which a process of calcification is by far very rapid and their occlusal movement completely different from human being[10, 11, 12, 13]. In histo-pathological studies on human cases, histological material was sampled from failures[14, 15]. The experimental conditions, for example, shape and type of implant used, presence or absence of mastication pressure, prosthetic technique and implant site were not consistant[16, 17, 18, 19, 20]. Because of these studies and apply the knowledge gained from them to clinical situation. The term of follow-up of implant case was not sufficiently long enough to evaluate clinical effect of functioning implant to the supporting tissues[21, 22].

Fig. 1. Species of primates

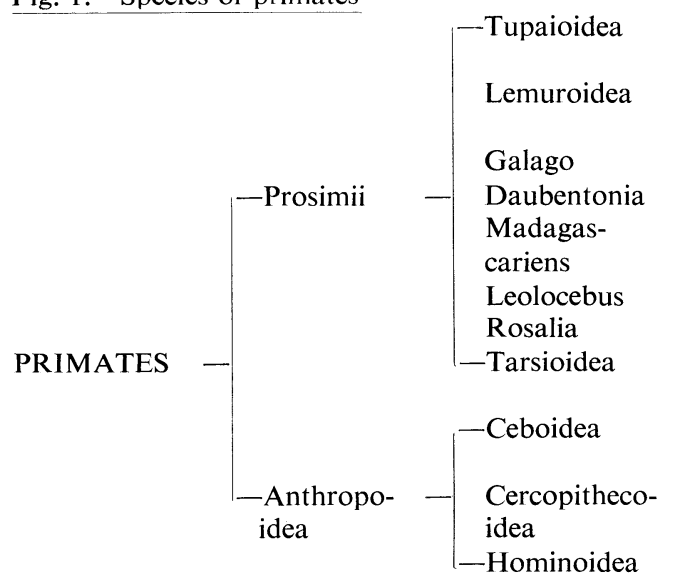

Tooth

formula

2.13 .3

3.13 .3

$\begin{array}{ll}2.1 & 3.3\end{array}$

2.13 .3

\begin{tabular}{ll}
1.0 & 1.3 \\
\hline 1.0 & 0.3
\end{tabular}

2.13 .2

2.13 .2

\begin{tabular}{ll}
$2.1 \quad 3.3$ \\
\hline 1.1 & 2.3
\end{tabular}

\begin{tabular}{ll}
1.12 .3 \\
\hline
\end{tabular}

\begin{tabular}{ll}
2.13 .3 \\
\hline 2.13 .3
\end{tabular}

2.12 .3

2.12 .3

\begin{tabular}{ll}
2.1 & 2.3 \\
\hline 2.1 & 2.3
\end{tabular}
Total number of teeth

38

36

18

32

32

36

32

32 
It is well known that long time is needed for the completion of basic structure of periodental tissue after the beginning of tooth eruption. In case of endosseous implant, long span of time must be necessary for the reconstruction of the supporting tissue around the implant.

Clear understanding of the process of adaptation of peripheral tissue and remodeling of bones to the functioning implants is important in making decision on the sustaining time span of dental implants which are used as semi-permanent endoprosthesis.

Taking into account the above considerations, a long term experiment was performed using an animal which closely approximate human being under identical clinical methodology.

Firstly, among primates as shown in Figure 1, those closely approximating human occlusion was selected. Macacus Irus is the primate of choice because of its similarity to human dental formula, total teeth number, and comparable jaw with thinner alveolar process found in human who is indicated for implant.

Blade-vent type implants of same size and shape were inserted utilizing the clinically identical insertion technique to the identical sites. Through the bridge, mastication force was brought to bear on the implants. Then the animals were fed and observed for the duration of the experiment.

Presently, the cases which have been followed the longest period after operation have surpassed seven years. Peripheral tissue around the implant has shown interesting macroscopic and radiographic findings.

The primary report of this experiment was confined to those cases of one to six months after operation. Macroscopic, radiographic and histological findings were obtained regarding changes of peripheral tissue around the endosseous implants.

\section{Materials and Method}

After importing experimental animals Macacus Irus, they were administered BCG and various immunization shots, examined for virus diseases peculiar to monkey, and given necessary and preventive treatments. These animals were fed under supervision for 3 months at the government experimental animal inspection center and were certified to be healthy. During the additional 3 months period when the animals were fed and housed in the school experimental animal facility, blood, serum, and urinary laboratory tests were performed. Macacus Irus whose test results were ascertained to be within normal value were used. They were three adult monkeys weighing $3.8-4.5 \mathrm{~kg}$ with all permanent teeth erupted.

As foods, crackers, bananas, fresh fruits such as apples and oranges, sweet potatoes, and dried small fish were given. Each animal was kept in a separate cage and fed individually.

The blade-vent endosseous implant called simply blade from now on was used. It was made of commercially pure titanium in the proportion as specified in Table 1. The shape of implants with buccolingual thickness is $1.3 \mathrm{~mm}$, width of $18 \mathrm{~mm}$, length of $8 \mathrm{~mm}$, and circular vents of $3 \mathrm{~mm}$ diameter is shown in Figure 2. (Name of various parts of the blade are in Figure 2). The metal surface of the implant was sand-blasted and passivated. The implants were de-greased in acetone and then cleaned by ultra- 
Table 1. Chemical composition and strength of a blade implant used in the experiment.

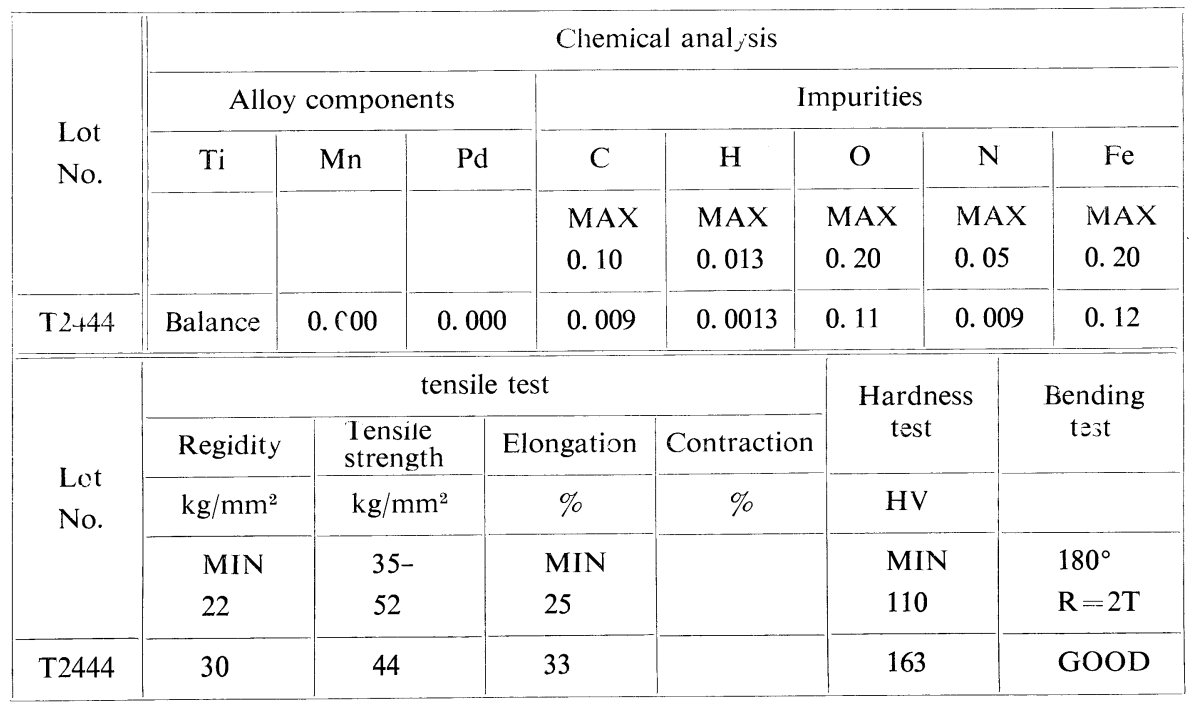

\section{Thickness $1.3 \mathrm{~mm}$}

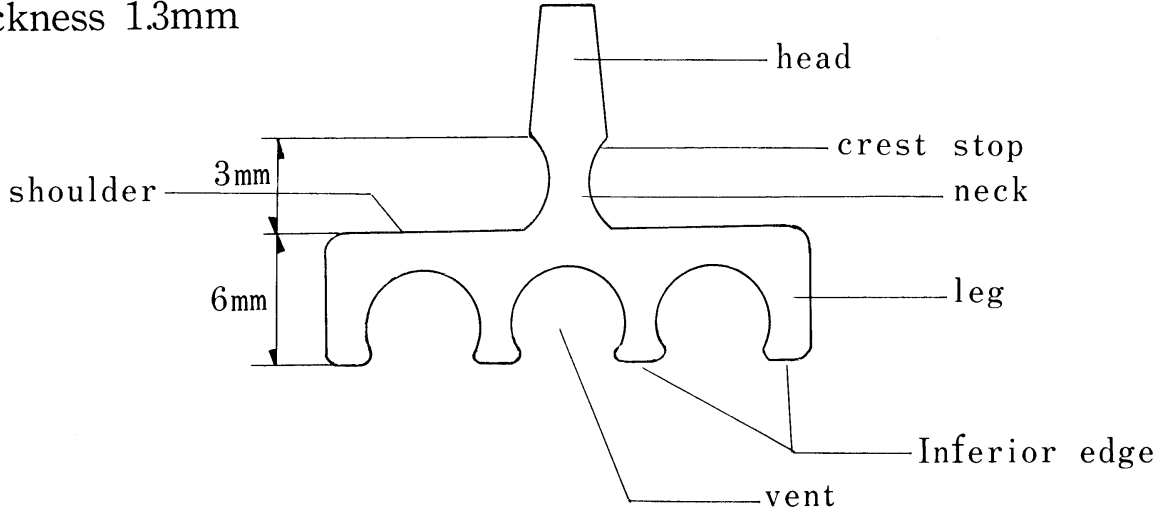

Fig. 2 Name of various parts of the blade.

sonic bath. Followed by autoclave, and stored in ethylene oxide gas until surgery.

The posterior teeth area of both sides of mandible was selected as the implant site. Four months before the blade insertion, P2, M1, M2 and M3 had been removed and healing of bone had been confirmed radiographically. With respect to the insertion technique, at first the incision of gingiva along the alveolar crest of the implant site was made to expose the alveolar process by elevating the mucoperiosteal flaps from the bone surface. Next, a narrow slot of approximate width of $1 \mathrm{~mm}$, depth of $10 \mathrm{~mm}$, and length of $20 \mathrm{~mm}$ was prepared. Using \#701 bar under the spray of sterile physiological saline. Then, the implant was tapped lightly so that the shoulder 
Table 2. Experimental schedule.

\begin{tabular}{|c|c|c|}
\hline Side of mandible & R & L \\
\hline Animal Month & \\
\hline A & 1 mo. & 3 mo. \\
\hline B & 2 & 1 \\
\hline C & 2 & 3 \\
\hline
\end{tabular}

Note: Numbers indicate period of month(s) from implant insertion to sacrifice.

is buried more than $2 \mathrm{~mm}$ below the edge of the narrow slot of the alveolar bone. The confirmation was made that the implant was inserted properly to the position where the bottom edge of the head is in contact with the alveolar crest. Finally the mucoperiosteal flap was repositioned, pressed firmly against the bone surface and sutured. After the strong primary retention of the implant was confirmed, prosthetic works were begun. One week after operation, the four unit fixed bridge consisting of full cast crowns made of platinum-gold alloy was cemented on anterior anchor of natural tooth and posterior anchor of the implant head. Two weeks after operation, occlusal relation was adjusted by using an articulating papers of $15 / 1000 \mathrm{~mm}$ in thickness.

The implants were inserted at various times to each side of mandible in region of each experimental animal according to the staggered schedule of Table 2 paying attention to minimize the individual differences.

Intraoral observations were made immediately after implant insertion and also at one week, two weeks, one month, three months, and six months periods under general anaesthesia by taking pictures and periapical radiography and recording macroscopic findings. After scheduled observation period was over, all the animals were sacrificed on the same day.

Three pairs of left and right bone blocks were prepared from mandible of all animals and these were divided into two separate groups each consisting of 1,2 , and 3 mouths P.O. bone blocks. One group of bone blocks was immediately fixed in $1 / 10$ neutral formalin solution for preparing microscopic specimen.

The other group of bone blocks was used for macroscopic observations. They were prepared as follows:

The bridge was removed to show gingival conditions around the implant and tooth. Elevating the mucoperiosteal flap to expose the tissues covering the shoulder, and removing the bone plate positioned lingual to the blade, it became possible to observe the peripheral tissue around the blade bucco-lingually.

For microscopic observations, each of the three pieces of formalin fixed bone blocks was sliced through the head and shoulders of implant in a vertical frontal direction into four smaller sections. After these were decalcified in $5 \%$ nitric acid, the blade was carefully dislodged by slowly pulling in the mesio-distal direction. 
When difficulty was encountered in dislodging the blade, tissues over the shoulder were incised with surgical knife. Then, twelve sections were washed for 24 hours under running water, followed by dehydrating them through an alcohol glass line. Then embedded in paraffin and/or celloidin and sliced into semi-continuous sections. Each of these sections were then stained in either hematoxylin-eosin, MG (MassonGoldner), AFMG or Azan stain.

\section{Results and Discussion}

\section{A. Intra-oral Observation}

Almost all of the bleeding stopped when suture was finished which was in the average 25 minutes after the start of surgery.

For one to three days after operation, gingiva at implant site remained slightly tense; however, the color tone recovered to normal within one week P.O. The incised area of gingiva was cured in primary wound healing process to allow removal of suture by one week P.O..

By one month P.O., occlusal surface of the bridge showed some glittering occlusal facets caused by attrition, which indicated that the implant bore mastication force through the bridge as shown in Figure 3. By one month P.O. the marginal gingiva was butt-jointed to the neck of implant with incised surface of gingiva against it. In the three month P.O. case, the margin of gingiva became rounded and rose along the post of implant. In the six month P.O. case, the shape of marginal gingiva was seen to be similar to the gingiva of natural tooth.

The mobility of the implant and bridge (Prosthesis) was practically not delectable by one month P.O. By three months P.O. bucco-lingual mobility increased slightly to the degree of Miller's Class I. By six months P.O., the degree of mobility was reduced to approximate closely that of the anterior natural tooth.

The tartar was always deposited around the neck of implant; however, the marginal gingiva could be seen to be intact in shape and color tone, showing no adverse state of reddening or swelling. Blood or inflammatory exudate from the neck of implants were not observed by six months P.O.. Gingiva was seen tenaciously encircling the neck to the degree that even a piece of dry filter paper could hardly be inserted by 6 months P.O..

\section{B. Macroscopic Findings}

The gingiva of bone blocks from one, three and six months P.O. cases which contained the implant were incised in mesio-distal direction at $2 \mathrm{~mm}$ lingually from alveolar crest, and the mucoperiosteal flap was elevated to expose the tissues covering the shoulder top. This is the site where there was blood clot covering the shoulder top just after operation. As shown in Figure 4, in the one month P.O. case, semitransparent white tough soft tissue was found over the shoulder. This newly regenerated tissue was fused to lamina propria of the adjacent gingiva and periosteum. Also it became the lower layer of marginal gingiva which encircled the neck of implant.

In the three month P.O. case, this soft tissue could not be seen directly beneath the mucoperiosteal flap. It had changed to hard tissue fusing with the surrounding bones. In the six month P.O. case, the shoulder of implant was covered with layers of hard and soft tissue which were hardly distinguishable from the surrounding 


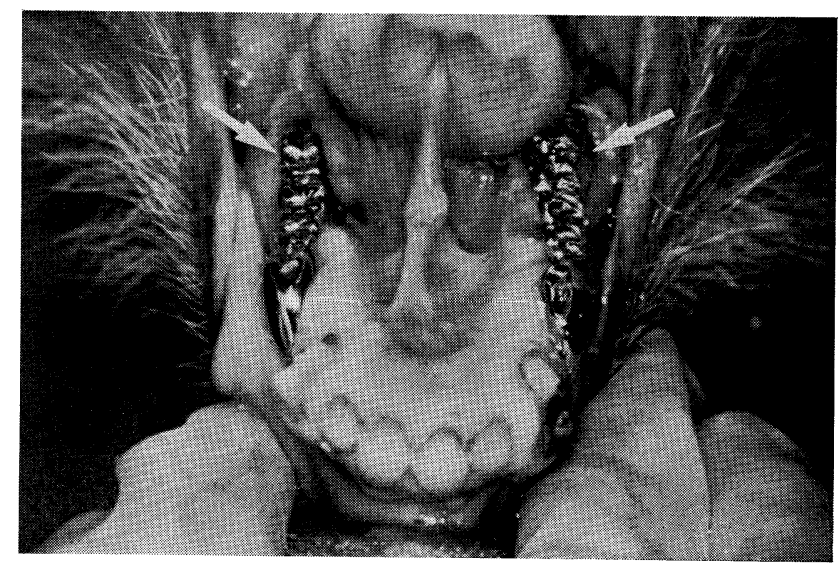

Fig. 3. Intra-oral picture showing implant prostheses $(\downarrow)$ inserted in lower posterior free-end missing on both sides

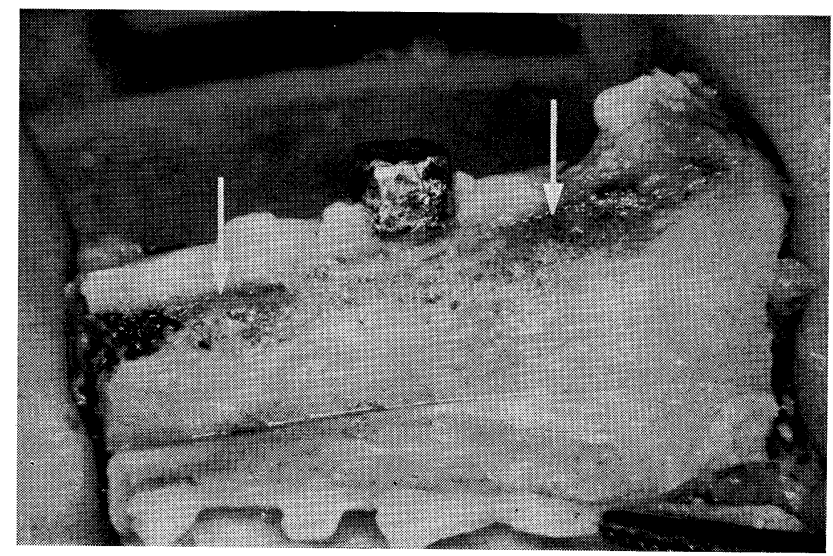

Fig. 4. Channelled area $(\downarrow)$ over the shoulder was filled with new bone

tissues. The surface of the hard tissue was porous similar to the surface of alveolar process rather than that of cortical plate of the bone block. The layers of hard and soft tissue were removed to expose the shoulder. Then, an attempt was made to remove the implant by pulling up by hand which proved to be not effective as it was firmly retained in the bone. Therefore, lingual bone plate was removed to expose the side of the blade. Again an attempt to remove it was made by pulling up by hand, but still it could not be freed since the new growth of tissue had interlocked within the vents. Finally, it was necessary to force the blade bucco-lingually to remove it. The strong resistance against its removal from the bone can be considered to be an indication of firm stability of the implant. As shown in Figure 5, after the implant 
was removed, inside surface of peripheral tissue which were in contact with it could be examined. The tissue in direct contact with the blade was a milky white semitransparent soft tissue which completely covered the metal parts of neck, shoulder, and inside of the vent. Inside surface of the new soft tissue was smooth and moist, showing the imprint of the horizontal line at $2 \mathrm{~mm}$ interval on the surface of blade. This is an unequivocal proof that the surface of the tissue was in intimate contact to the implant. The outside of the new soft tissue which faced the surrounding bone had been attached together. In the one month P.O. case, the strength of attachment was so weak that the tissue was easily peeled off from the bone with a pair of tweezers. In the three and six months P.O. cases, attachment between the new soft tissue and the surrounding bone became impossibly firm to peel them apart manually.

Compared to the thickness of the blade of $1.3 \mathrm{~mm}$, the new soft layer was so thin that it was about $1 / 10$ of it. The new soft tissue layer will be named neointima in this paper.

The vents were filled with the newly developed soft and white semi-transparent tissue. It was difficult macroscopically to detect harder tissue inside the vent. But in the three to six months P.O. cases, it was clear that the circular new bone tissue had

Tab.e 3. Macroscopic Findings.

\begin{tabular}{|c|c|c|c|}
\hline & One month P.O. & Three months P.O. & Six months P.O. \\
\hline $\begin{array}{l}\text { Gingival incision } \\
\text { wound }\end{array}$ & Fused & Cured & Cured \\
\hline $\begin{array}{l}\text { Marginal gingiva } \\
\text { around the neck }\end{array}$ & $\begin{array}{l}\text { Butt jointed to the } \\
\text { neck }\end{array}$ & $\begin{array}{l}\text { Rounded at margin } \\
\text { of gigiva }\end{array}$ & $\begin{array}{l}\text { Rose up along the } \\
\text { post }\end{array}$ \\
\hline $\begin{array}{l}\text { Tissue above the } \\
\text { shoulder (site of } \\
\text { channeling narrow } \\
\text { slot) }\end{array}$ & $\begin{array}{l}\text { White semi- } \\
\text { transparent soft } \\
\text { tissue, fused to the } \\
\text { muco-periosteal flaps }\end{array}$ & $\begin{array}{l}\text { New porous bone } \\
\text { and soft tissue layer }\end{array}$ & $\begin{array}{l}\text { New bone and } \\
\text { neointima cover the } \\
\text { shoulder }\end{array}$ \\
\hline $\begin{array}{l}\text { Neo-intima (newly- } \\
\text { developed soft tissue } \\
\text { layer) }\end{array}$ & $\begin{array}{l}\text { White semi- } \\
\text { transparent thin soft } \\
\text { tissue layer, easy to } \\
\text { peeled from the bone }\end{array}$ & $\begin{array}{l}\text { Thickens, inside } \\
\text { surface shows } \\
\text { imprint of the } \\
\text { implant, appears } \\
\text { moist and smooth }\end{array}$ & $\begin{array}{l}\text { Becomes tough and } \\
\text { is firmly fused. } \\
\text { Thickness becomes } \\
\text { uniform. }\end{array}$ \\
\hline $\begin{array}{l}\text { Inside of vent (site } \\
\text { of channeling } \\
\text { narrow slot) }\end{array}$ & $\begin{array}{l}\text { Filled with white } \\
\text { semi-transparent soft } \\
\text { tissue }\end{array}$ & $\begin{array}{l}\text { Semi-transparent } \\
\text { thin layer completely } \\
\text { covers the inside of } \\
\text { vent. Circular new } \\
\text { bone tissue traveculae } \\
\text { regenerated in the } \\
\text { center of vent. }\end{array}$ & $\begin{array}{l}\text { New hard net } \\
\text { structure contains } \\
\text { bone marrow and } \\
\text { fused to the bone } \\
\text { trabeculae bucco- } \\
\text { lingually. }\end{array}$ \\
\hline $\begin{array}{l}\text { Resistance against } \\
\text { blade removal }\end{array}$ & \multicolumn{3}{|c|}{$\begin{array}{l}\text { a) Tissue covering the shoulder resists pull } \\
\text { b) Intimate contact of tissue bucco-ligually } \\
\text { c) Interlocking of newly developed tissue inside the vent }\end{array}$} \\
\hline
\end{tabular}


developed in the center of the vent which can easily be differentiated by color and hardness from neointima which is white semi-transparent and directly in contact with implant surface. The appearance of the new-bone tissue was white, hard and net-structured which contained red-colored soft tissue resembling the color tone of the bone marrow. The new bone tissue in the vents was connected to the bone trabeculae bucco-lingually. The site in the vents was filled with blood clot immediately after operation.

Macroscopic findings of the bone blocks are outlined in Table 2.

C. Radiographic Findings

A periapical X-ray film taken before the operation showed homogeneous arrangement of bone trabeculae of alveolar process at the implant site. Lamina dura

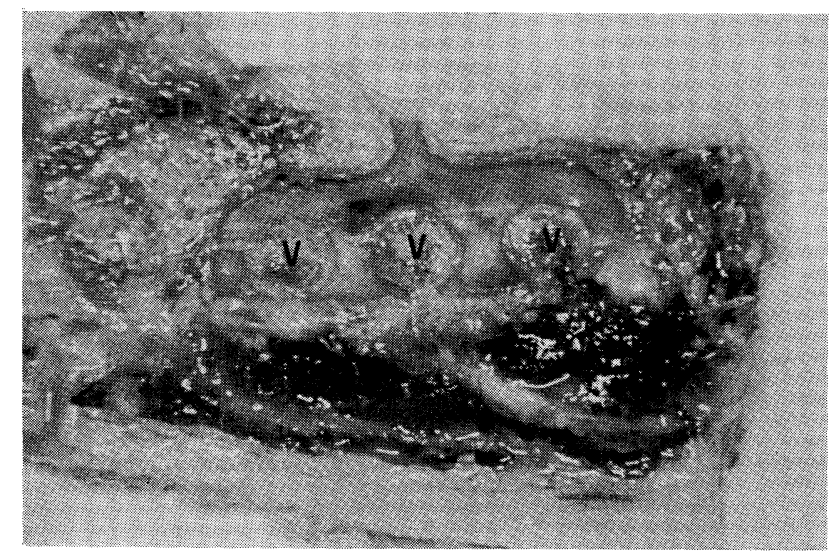

Fig. 5. The sectioned bone block shows neointima and fibrous bone filled in the vents $(\mathrm{V})$

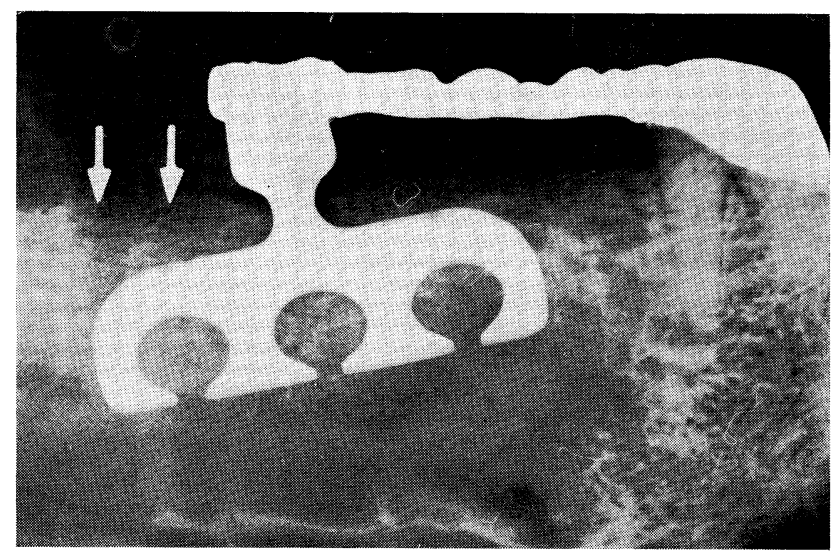

Fig. 6. Periapical X-ray taken soon after surgery showing bone loss due to chennelling $(\downarrow)$ 


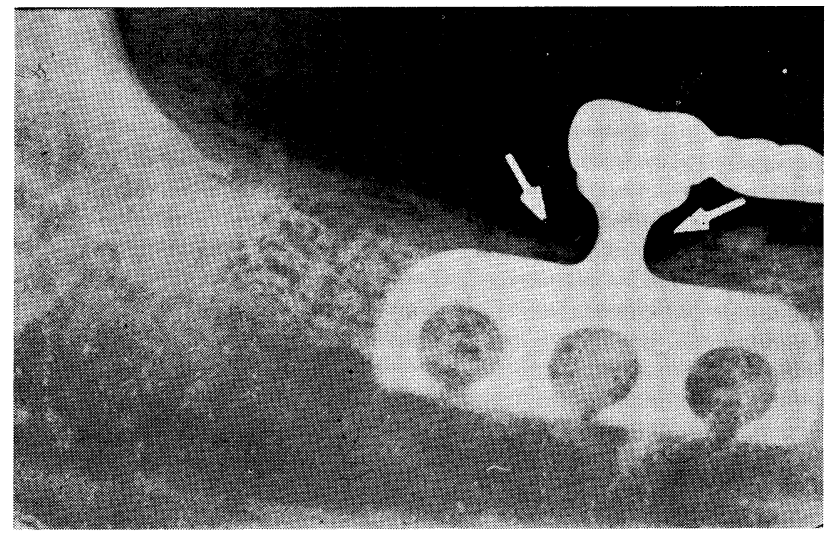

Fig. 7. Periapical X-ray showing localized saucer-shape radiolucent image $(\downarrow)$

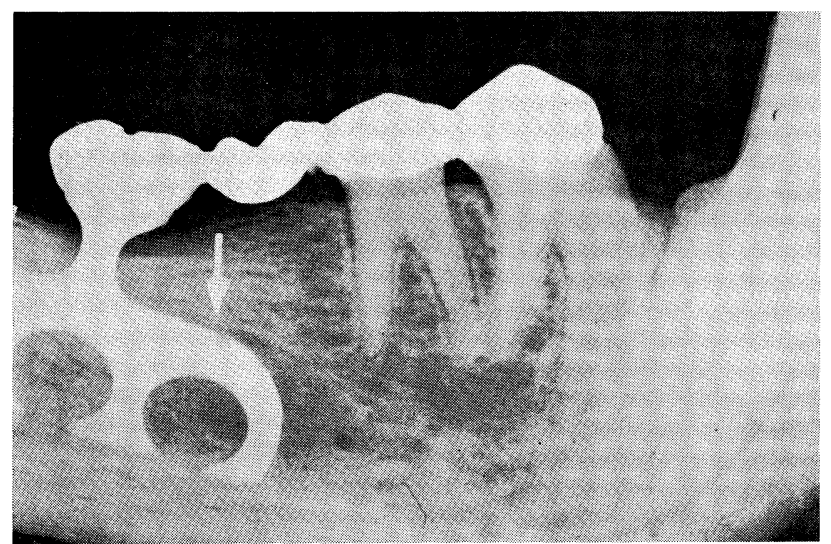

Fig. 8. Peri-implant space $(\downarrow)$ starts to appear in periapical X-ray

which was presented at the time of tooth extraction did not show on the X-ray film.

An X-ray film immediately after the operation showed a radiolucent image of real loss of narrow slot around the implant as shown in Figure 6.

On the X-ray film taken one month P.O., however, radiolucent image of a narrow slot became hardly distinguishable from its surroundings. This finding may suggest that the end of bone trabeculae which were cut for the preparation of a narrow slot has begun to be decalcified. At three months P.O., a thin saucer shaped radiolucency appeared at the alveolar crest along the lower surface of the head as shown in Figure 7. A slight decalcification may have been developed around all surfaces of the implant because of static pressure to it at insertion.

Generally in madible, alveolar bone where the head is in contact is thinner than 
the body of mandible where the blade is located. Therefore, even a slight change in thinner alveolar bone can show a detactable image on X-ray but the thicker body of mandible interface to show such image.

The X-ray film taken six months P.O., in addition to the findings in three month P.O. case, showed clearly a narrow radiolucent space over the shoulder as shown in Figure 8. This sort of finding was not yet observed in any other site.

D. Microscopic Findings

Figure 9 shows a low magnified microscopic photograph of a vertical frontal section of a bone block of the one month P.O. case. (Hematoxylin-eosin $\times 12$ ). The wedge-shaped artifact (I) seen in center is the site the blade had occupied. The space over the artifact (I) was made by incision for blade to removed after the specimen had been decalcified. If the part which was in contact with the blade is examined around the artifact, there can be seen a thin fibrous tissue which is thicker over the shoulder and continuous to periosteum covering the outer cortical plate and to lamina propria of gingiva. Figure 10 is an enlarged microscopic photograph of Figure 9, showing an artifact in center which had been occupied by the blade. The

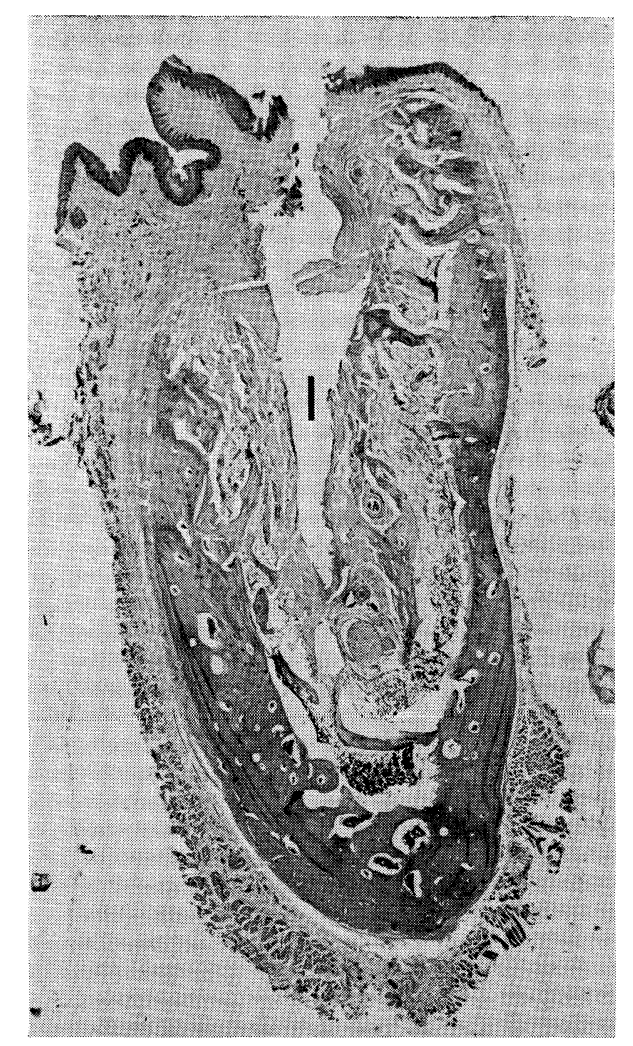

Fig. 9 Vertical frontal section of 1 month P.O. case. (H-E stain), $\times 12$; I: Blade insertion site. 
soft tissue layer on the side of the blade and around the inferior edge is extremely thin and the tissue layer is partly peeled off from the bone. Surrounding the blade there is a thin laminar bone tissue extending to the alveolar crest. The upper part of these bones is covered with connective tissue consisted of collagen fiber rich in fibroblast. The epithelium is thickened. The papilla of epithelium is rather disarrayed. In the lamina propria of gingiva, slight infiltration of inflammatory cells were observed, however, it was not detected in any other site.

Moreover, number of large and small blood vessels around the blade were observed. The osteocytes in the bone near the implant were stained. This finding indicated that the bone tissue was vital. The osseous tissue closely in contact with the implant shows an evidence of vitality. Sequenstrum or presence of giant cells that indicate foreign body reaction could not be observed.

The abovementioned findings about one month P.O. specimen indicate a picture of normal healing process of wound caused by preparation of a narrow slot.

Figure 11 shows a low magnified microscopic photograph of a specimen of vertical frontal section of the three-month P.O. case. $(M-G$ stain $\times 30)$ New bone

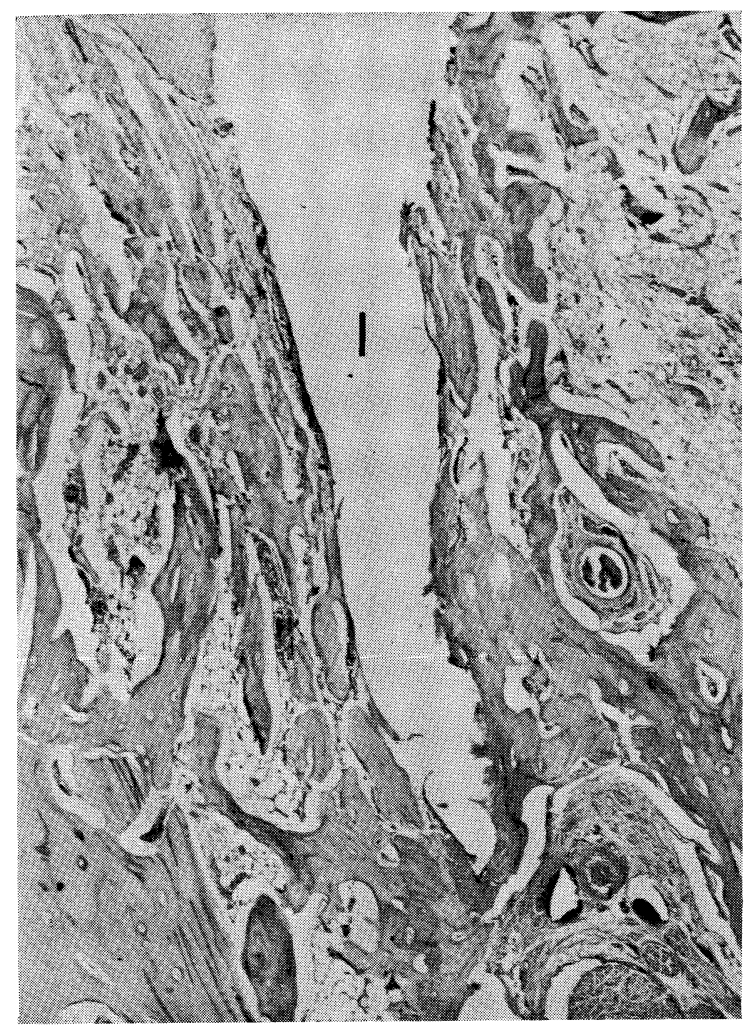

Fig. 10 Microscopic photograph of Fig. 9. $(\times 40)$. 
has regrown over the shoulder and neointima has completely surrounded the blade. This specimen is showing mesiodistal view of the blade and vents. The area the blade had occupied can be observed as two artifacts (I). Around these artifacts (I), neointima has grown thicker and especially the lower part of the blade was enclosed by a thicker collagen fibre layer rich in flattened fibroblast in company of abundance of small and large blood vessels compared to the one month P.O.

The collagen fibres in the neointima were arranged in orderly fashion paralleling the surface of implant. The fibrous layer increased in density as it got closer to the blade as shown in Figure 12 (AFMG stain $\times 70$ ). Surrounding bone trabeculae became thickened compared to the one month P.O. specimen. The central part of vent is filled with a new regenerated tissue. It can be ascertained that this new bone is continued to the bone trabeculae on both lingual and bucco sides. This area is the site where the bone had been lost when a narrow slot was prepared for insertion. It was filled with a connective tissue in one month P.O. specimen.

When the border area between the neointima and bone trabeculae was examined under high magnification, a flattened fibroblast layer could be observed on

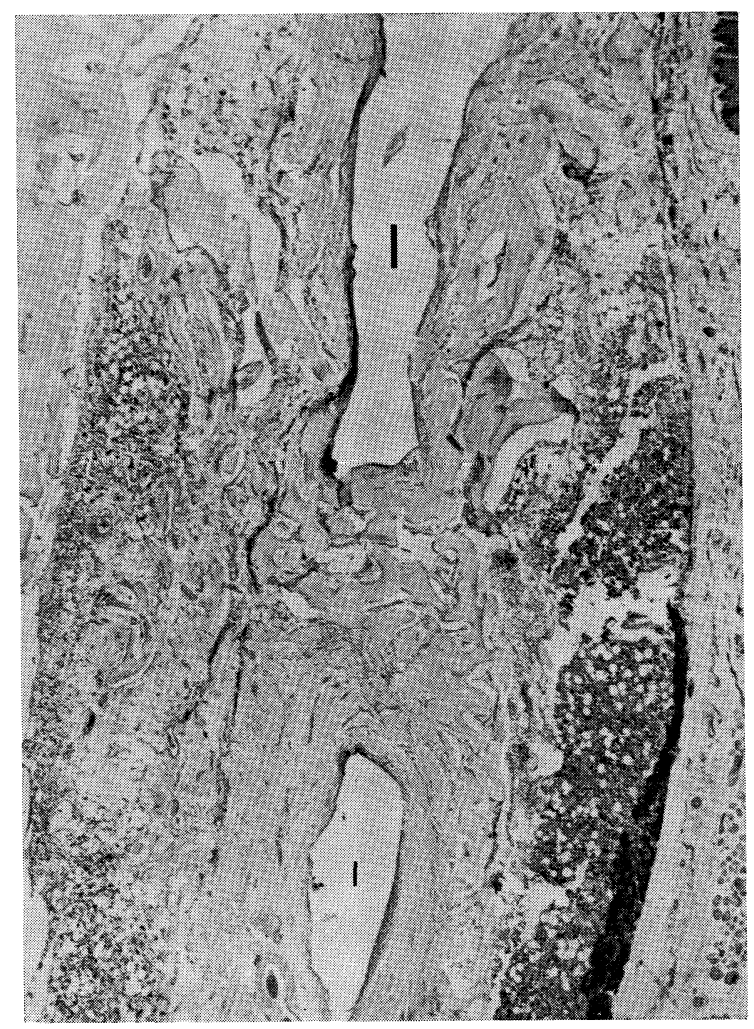

Fig. 11 Vertical frontal section of 3-months P.O. case. $(M-G$ stain) $\times 30$. 
the side of implant. On the other side of neointima, a layer consisting of mononuclear-cubical cells faced the periphery of a new fibrous bone. The new-fibrous bone contained a large number of osteocytes which had large lacuna. The number of osteocytes in the new bone is greater with comparison to that of the compact bone. These findings indicated the process of active fibro-ossification[23] as shown in Figure 13 (hematoxylin-eosin $\times 400$ ).

Figure 14 is a microscopic photograph of the specimen of the six months P.O. case. (Hemotoxylin-eosin $\times 10$ ). The centrally located oblong artifact is the site where the implant had been occupied. The thickness of neointima enveloping the entire artifact is nearly uniform. In comparison with one and three months P.O. cases, the number of fibroblasts in neointima had decreased and the fibres had become denser. Especially, neo-intima surrounding the inferior edge of the legs of the blade contained a few of the cell components and presented a tendon-like figure. It can be considered that a comparatively strong stress was dinamically being transmitted through the implant to the inferior edge area[24, 25]. A layer of bone trabeculae was arranged adjacent to the outside of neointima as shown in Figure 15 (hematoxylin-eosin $\times 30$ ).

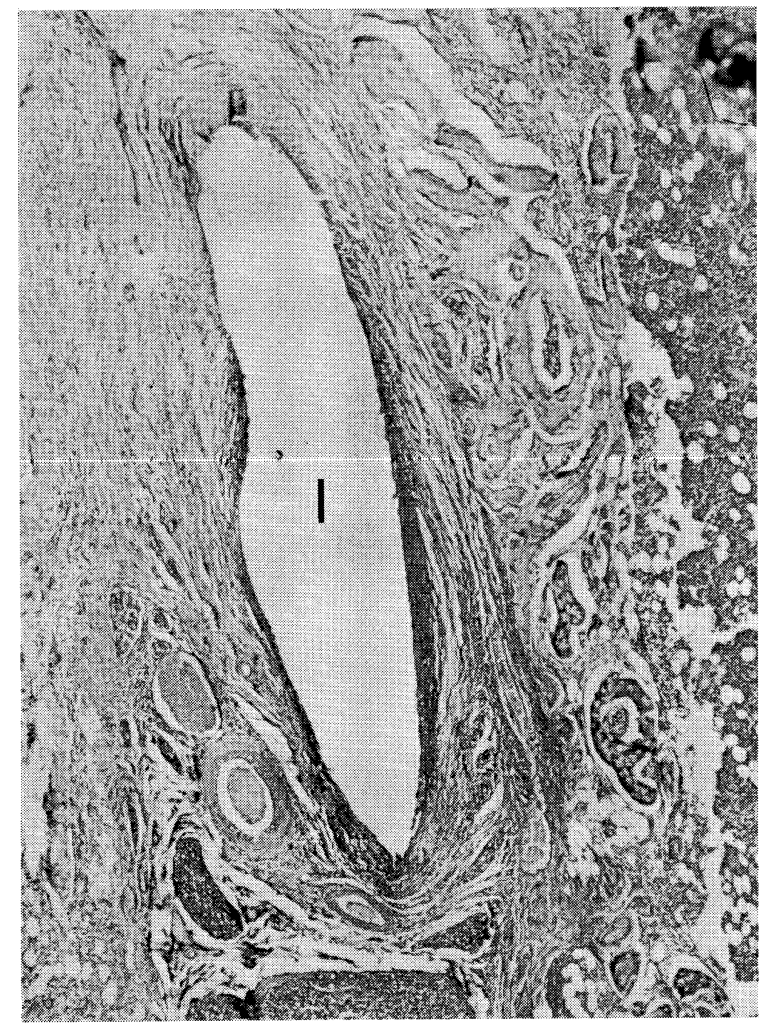

Fig. 12 Vertical frontal section of 3-months P.O. case (AFMG stain) $\times 70$. 


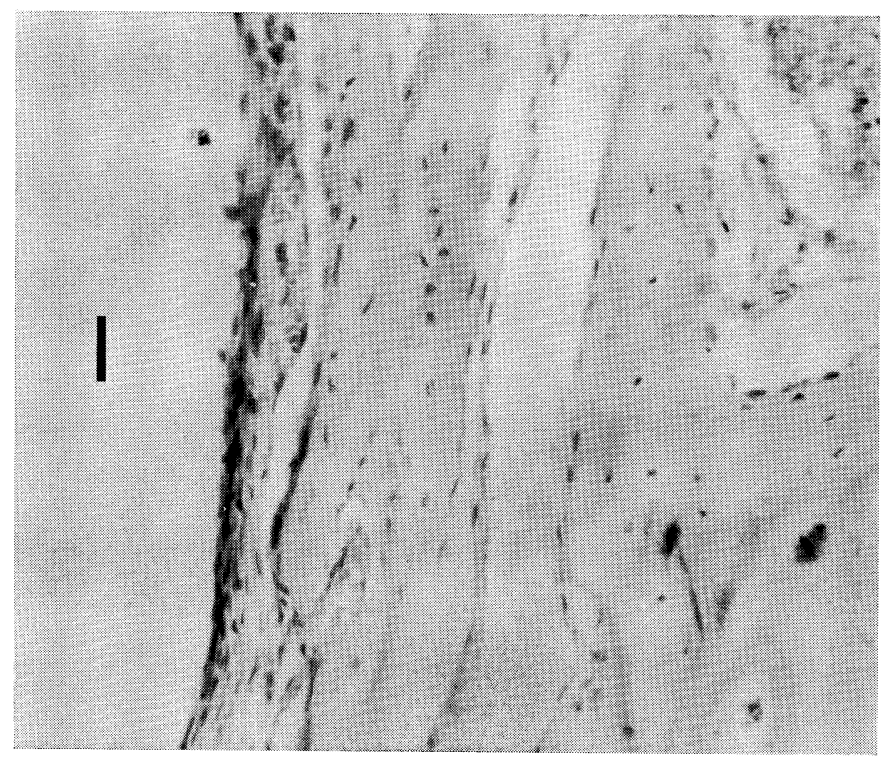

Fig. 13 Three montes P.O. case $($ H-E stain $) \times 400$.

Although it is usual that a few bone trabeculae are coarsely arranged in molar region inside of the mandible, findings in this specimen must be indicating the result of a new tissue and bone regeneration and remodeling to the implant after insertion.

Furthermore, a new bone is continued to bucco-lingual outer cortical plate as well as to alveolar bone. As shown in Figure 15, the lingual compact bone which was continued to new bone around the implant has been thickened. These findings may confirm that bone and tissue had supported the functioning blade and distributed masticulation stress to the peripheral tissues.

\section{Summary}

With aim of histological study on the changes and response processes of surrounding tissue to endosseous functioning dental implant, we had inserted the blade implant in the mandibular molar region of Macacus Irus with the identical technique being applied clinically. Applying usual mastication force to the implant which served as the posterior abutment of fixed bridge and feeding for an expanded span of period, the animals were closely observed.

As a primary report of the present experiment, macroscopic, radiographic, and microscopic findings of one to six months P.O. cases were obtained. Summary of the findings is as follows:

1) By six months P.O., a thin collagenous layer, neo-intima of approximately $1 / 10 \mathrm{~mm}$ in thickness had uniformally developed between the implant and its surrounding bone. The proportion of cells and fibres and thickness of neointima had changed with the passing of time after operation. 
2) Neointima was osteogenetic tissue of fibrous bone which regenerated around the implant[26, 27, 28, 29].

3) The inner layer of gingival sulcus around the implant neck came from extension of gingiva, lacking in papilla, and underlined with neointima which was lamina propria. Under-growth of epithelium did not develop deeper than alveolar bone crest.

4) There was an infiltration of chronic inflammatory cells to the base of gingival sulcus and to underlining collagen layer to the same extent as that which affected the area around the natural tooth used as a control. There was no finding of inflammation at any other site nor was there any rejection response, foreign body reaction, and sequestrume of bone.

5) Neointima was in intimate contact with the implant. New bone and neointima surrounded the implant and grew into the vents. It can be considered that they had played an important role of effective stabilization and support of the implant.

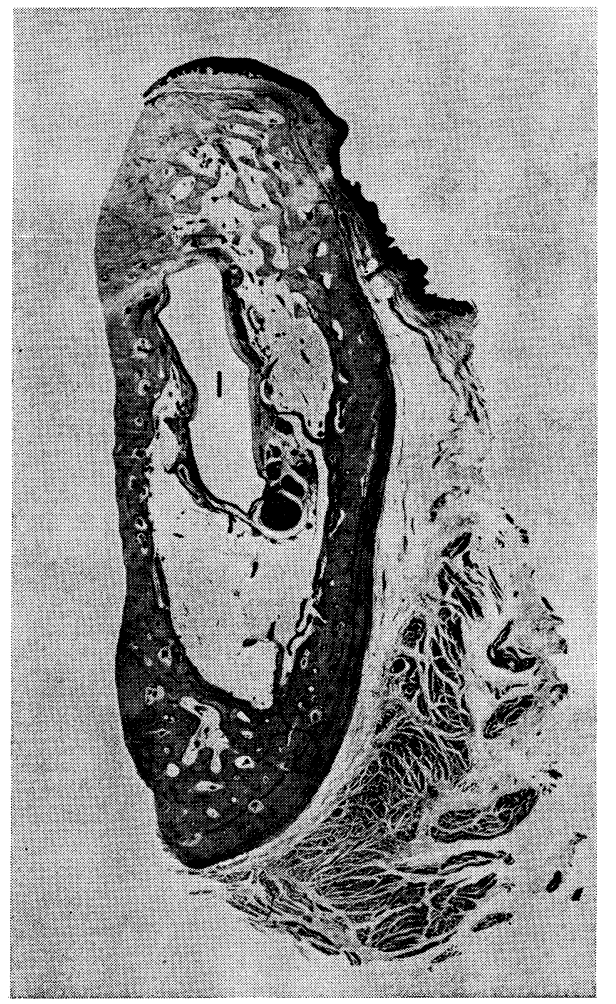

Fig. 14 Vertical frontal section of 6-months P.O. case (H-E stain) $\times 10$. 


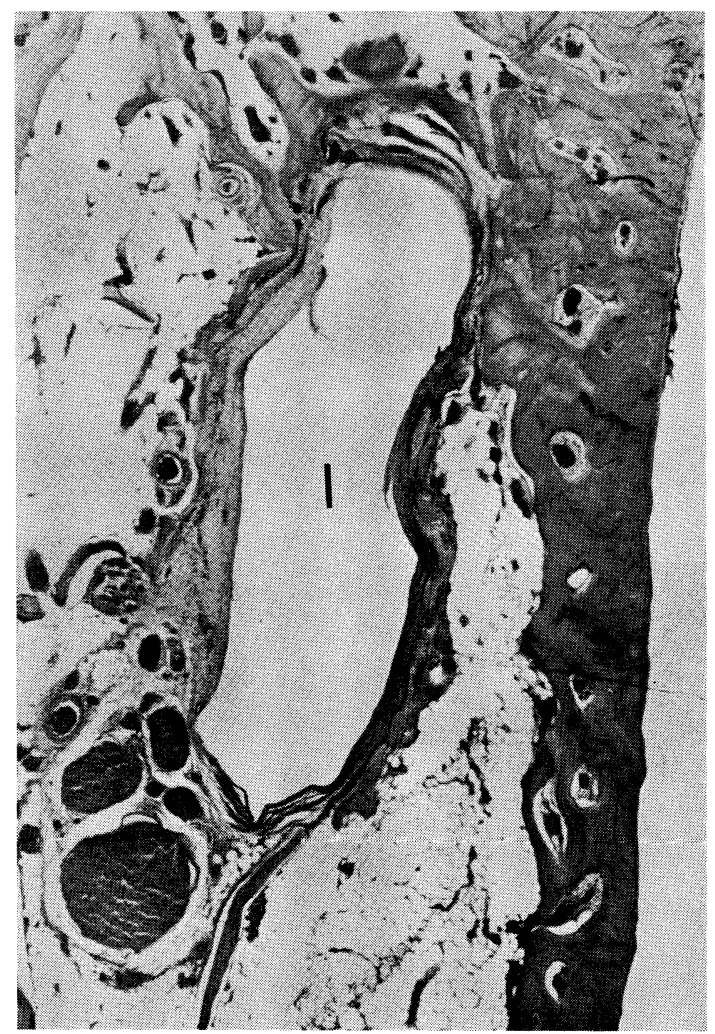

Fig. 15 Six months P.O. case $($ H-E stain $) \times 30$.

6) The arrangement of fibres in neointima and regeneration of new bone showed a definite order along the implant by one to six months after operation.

7) Periapical X-ray films showed suitable informations which were interpreted as changes in the bone and neointima.

The above findings are very encouraging to the clinical application of blade implants. However, final conclusion must be reserved until more observations of longer term follow-up results have been gathered and evaluated.

\section{References}

[1]* Nitikuni, T. Sairenji E. and Yanagisawa S.: Case Presentation of Metalic Implant, Nichidai Shigaku, 46, 155-157, (1971).

[2] Linkow, L. I.: The Blade Vent, A New Dimension in Endosseous Implantology, Dental Concept, Spring, 2-11, (1968).

[3] Linkow, L. I. and Cherchéve, R.: Theories and Techniques of Oral Implantology, Vol. 1 270-276, C. V. Mosby Co., Saint Louis, (1970).

[4]* Fukuyo, S. and SANo, M.: Endosseous Implant-Blade Vent, Shikai Tembo, 38, 827-836, (1971).

[5]* SaKamoto, Y.: Blade Implant Cases, Hotetsu Rinsho, 7, 143-148, (1974).

[6]* Yanagisawa, S.: On Oral Implantology, Shikai Tembo, 39, 847-852, (1972); 40, 87-99, (1972). 
[7]* Yanagisawa, S. and Sairenji, E.: The Role of Oral Radiology in Dental Implants, 97-104, Proceedings of 3rd International Congress of Maxillofacial Radiology, Kyoto, (1974).

[8]* Yanagisawa, S., Nakajo, M. and Yoshimine, K.: Prognosis and follow-up result of implant cases, Shikai Tembo, 43, 103-114, (1974).

[9]* Sakuma, Y., Ninkuni, T., Sairenji, E., Yanagisawa, S. and Fukuyo, S.: Dynamic Stress analysis using wedge shape models, The Dental Implant, 1, 11-16, (1973).

[10] Herschfus, L.: Histopathological Findings on Vitalium Implants in Dogs, J. Prosth. Dent. 4, 413-419, (1954); Further Pathologic Studies of Implants in Dogs, J. Imp. Dent., 2, 20-27, (1955); Histopathologic Studies of Five-Years Implants in Dog, J. Imp. Dent., 4, 12-21, (1957).

[11] Babbush, C. A.: Endosseous Blade-Vent Implants, A Research Review, J. Oral Surg., 30, 168-175, (1972).

[12] Richards, L. W., Gourley I. M. and Cordy D.R.: Titanium Endosteal Dental Implants in the Mandibles of Dog, J. Prosth. Dent., 31, 198-203, (1974).

[13] Kaketa, T. and Suzuki, K.: Histopathological Findings on Endo-osseous Implants in Dogs, Bull Tokyo Dent. Coll., 10, 61-70, (1969).

[14] Linkow, L. I.: Histopathologic and Radiologic Studies on Endosseous Implants, Dental Concepts 2-12, Fall-Winter, (1968).

[15] Linkow, L. I. and Cherchéve, R.: Theories and techniques of Oral Implantology, vol 1, 81133, C. V. Mosby Co., Saint Louis, (1970).

[16] Frank, A. L. and Abrams, A. M.: Histologic Evaluation of Endodontic Implants, J.A.D.A., 78, 520-524, (1969).

[17] Harries, R. and Lossin, C.: The use of Cobalt Chromium Alloy and Titanium Endosseous Dental Implants, Aust. Dent. J., 4, 94-108, (1971).

[18] Block, V. P. and Baden, E.: Tissue Tolerance of Metalic Implants, J.A.D.A., 83, 856-859, (1971).

[19] Bodine, L. R. and Mohammed, I. C.: Histologic Studies of a Human Mandible supporting an implant denture, J. Pros. Dent., 21, 164-176, (1969); Implant Denture Histology, Gross and Microscopic Studies of a human mandible with a 12-years Subperiosteal Implant Denture, Dent. Clin. N. Am., 14, 145 Jan. (1970).

[20] MACK, A.: Histological Investigation of Effects of Subperiosteal Dental Implants in Monkeys, Brit. Dent. J., 108, 217-224, (1960).

[21] Armitage, J., Natiella, J., Greene, G., Jr. and Meenaghan, M.: An evaluation of early bone changes after the insertion of Metal Endosseous Implants into the Jaws of rhesus monkeys, OSOMOP, 32, 558-568, (1971).

[22] Natiella, J. R., Armitage J. E., Meenaghan M. E. and Green F. W.: Tissue Response to Dental Implant Protruding through Mucous Membrane, Oral Science Review, 5, 85-105, (1974).

[23] Frost, H. M.: The bone Dynamics in Osteoporosis and Osteomalacia, 11-35, Charles C. Thomas Co., Springfield, Ill., (1966).

[24] Becker, R. O. and BAssett, C. A. L.: Biophysical studies of Bone under mechanical stress, in Bone Biodynamics, Little, Brown and Co., Boston, (1964).

[25] EnLow, D. H.: Wolf's low and the factor of architectonic circumstance, Handbook of Facial Growth W. B. Saunders, Philadelphia 236, 348, (1975).

[26] Young, R. W.: Regional differences in cell generation time in growing Rat tibial, Expl. Cell Res., 26, 562-567, (1962).

[27] Young, R. W.: Specialization of Bone Cell, in Bone Biodynamics Edt. Frost H., Little, Brown and Co., Boston, 117-139, (1964).

[28] OWEN, M.: Cell population kinetics of an osteogenetic tissue I, J. Cell Biol., 19, 19-32, (1963).

[29] Owen, M. and MacPherson, S.: Cell population kinetic of an osteogenetic tissue II, J. Cell Biol., 19, 33-44 (1963).

* Written in Japanese 